\title{
Determinants of Global Pricing of Crude Oil- A Theoretical Review
}

\author{
Gyagri M. ${ }^{1}$, Amarfio, E. M. ${ }^{1}$ and Marfo. S A. ${ }^{1}$ \\ ${ }^{1}$ Department of Petroleum Engineering, Faculty of Mineral Resources Technology, \\ University of Mines and Technology, Tarkwa, Ghana
}

\begin{abstract}
Crude oil affects almost all activities of our modern day hydrocarbon society irrespective of the shifting trend to green energy. The ever increasing importance and demand of oil globally, has led to its highly complex market and pricing system. The purpose of this paper is to give a general understanding of the crude oil market and the formation of the oil pricing system in the long and short term. Understanding the factors behind this complex market system is vital as it can aid in critical decision and policy making. When the oil market began in the 1860s factors such as the quantity of oil that was demanded and flooded into the market were the main determinants of its price. Overtime the emergence of major oil companies dominated the market scene till their places were taken by governments in consumer and producer countries. These governments decisions, coupled with other organisations like the Organisation of Petroleum Exporting Countries, (OPEC), Organisation for Economic Co-operation and Development (OECD), geopolitical conflicts and wars, economic and industrial growth and development are now influential factors that affect crude prices. Other contributors to the complex market system include futures market contracts, speculators in the commodity market, refinery capacities, the value of the dollar and the weather. Crude oil prices thus change over time and cannot be attributed to one single market factor as it has spawned a highly complicated market system dependent on several different factors.
\end{abstract}

Keywords: Hydrocarbon system, crude pricing system, refinery capacity, determinant, analysis, critical decision

\section{INTRODUCTION}

Crude oil, is an invaluable source of energy all over the world as it affects the development and activities of almost all governments and its people. The energy, industrial, domestic, transportation and economic sectors heavily depend on crude oil. According to the BP statistical review of world energy in June 2016, oil remained the world's leading fuel, accounting for $32.9 \%$ of global energy consumption ${ }^{[1]}$.

This ever increasing demand and emergence of crude oil as a highly sought after global commodity after its commercial inception in the 1860s has accounted for its market complexity and price volatility. Various factors such as oil production and demand, government decisions and activities, multinational oil companies, geopolitical conflicts and economic activities and entities such as the Organisation of Petroleum Exporting Countries (OPEC), have been identified as contributors in the determination of oil prices.

Because crude oil plays a major role in almost all modern day activities there is the need to identify and understand the factors influencing its pricing as this can aid in governmental, organisational and individual decision making, planning and forecasting.

The objective of this research is to identify the factors that influence global crude oil prices by review of relevant literature on the subject.

\section{Determinant of the Crude Oil Pricing System}

The term Crude Oil refers to a naturally occurring, unrefined flammable liquid composed predominantly of hydrocarbons and found in oil reservoirs primarily associated with sedimentary rocks. This resource is limited and nonrenewable, also known as fossil fuel, thus it cannot be replaced naturally after consumption ${ }^{[2]}$. 
Here we seek to provide relevant facts on the extraction and production of crude oil, it's processing and pricing on the global market. We also try to identify the factors that influence or determine the price of oil.

\subsection{The Oil Market}

The oil market consists of a complex range of industries all performing a wide variety of activities from the upstream through the mid-stream to the downstream of the petroleum sector. Crude oil resides mostly in underground reserves that are difficult to reach and whose ownership is highly sought after. The crude oil is extracted by either a national company or a private company after the right and necessary petroleum arrangements have been established. Crude oil after its extraction is separated from natural gas, water and other side products such as harmful gases, organometallic compounds and basic sediment and water (BSW). It is then sold and transported to refiners around the world by tanker ships, oil pipelines etc. The oil at refineries then undergo various chemical and physical processes such as atmospheric distillation, hydrocracking and blending to transform them into useful products which are sold on further markets to industrial users and retailers. The end products of oil reach consumption in the form of transportation fuel such as gasoline and diesel, asphalt for road construction, electricity, plastics, petrochemicals and many more ${ }^{[3]}$.

\subsection{Commodity Pricing}

Crude oil is traded internationally in US dollars per American Petroleum Institute (API) barrel of 42 US gallons at $60^{\circ} \mathrm{F}$ and atmospheric pressure, also known as stock tank barrel (stb). Crude oil differs greatly in physical properties and quality because of the varying conditions responsible for its formation. Some of the properties of crude oil include density, pour point, sulphur content, API gravity and colour.

Because of the differences in the properties if oils, they are primarily categorized according to their API gravity and sulphur content. These two properties are important in determining the commercial value of oils. API gravity is a measure of oil gravity compared to the gravity of water, expressed in degrees. The higher the API gravity of crude oil, the lighter the oil. Sulphur content also represents the amount of sulphur present in the oil expressed in percentage by weight in crude. Crudes with negligible amount of sulphur are termed sweet crude whilst sour crudes have significant sulphur content.

The API gravity of crude oils vary from $5{ }^{\circ} \mathrm{API}$ to $55^{\circ} \mathrm{API}$. Average crudes have a $25^{\circ} \mathrm{API}$ to $35^{\circ} \mathrm{API}$ range, whilst light crudes range from 35 to $45^{\circ} \mathrm{API}$ and heavy oils below $25^{\circ} \mathrm{API}{ }^{[4]}$. Light and sweet crude oils are more desirable and usually priced higher than heavy, sour crude oils. This is because gasoline and diesel fuel which typically sell at a premium to residual fuel oil or other "bottom of the barrel" products, can usually be produced easily and cheaply using light sweet crude oil and these crudes require far less sophisticated and energy intensive processes. Sour crudes are corrosive and require extra treating costs ${ }^{[5]}$.

The amount of entrained water and salt content in crudes also influence the price refineries are willing to pay for each barrel of crude oil, regardless of where in the world it is produced (4). Some of the major crude oil price benchmarks include; West Texas Intermediate ("WTI", United States), Brent Blend (North Sea, Europe) and the OPEC reference basket made up of 13 (Bonny Light, Arab Light etc) blends across OPEC member countries. Prices of these benchmark crudes are highly correlated; WTI and Brent have been almost equal for decades, with their spread for twenty years averaging at $\$$ 1.44 in favor of WTI.

Oil suppliers and buyers meet on commodity exchanges to trade these various blends of oil. Commodity exchanges trade in options, futures and physical delivery of crude oil and various oil products. Some of the major exchanges in which oil is traded are; The New York Mercantile Exchange(NYMEX) in New York City and the Intercontinental Exchange (ICE) in London and Atlanta ${ }^{[3]}$.Figure 2.1 shows the density and sulphur content of some blends of crude oil and Figure 2.2 also shows the prices of some oil blends from 1996 to 2016. 


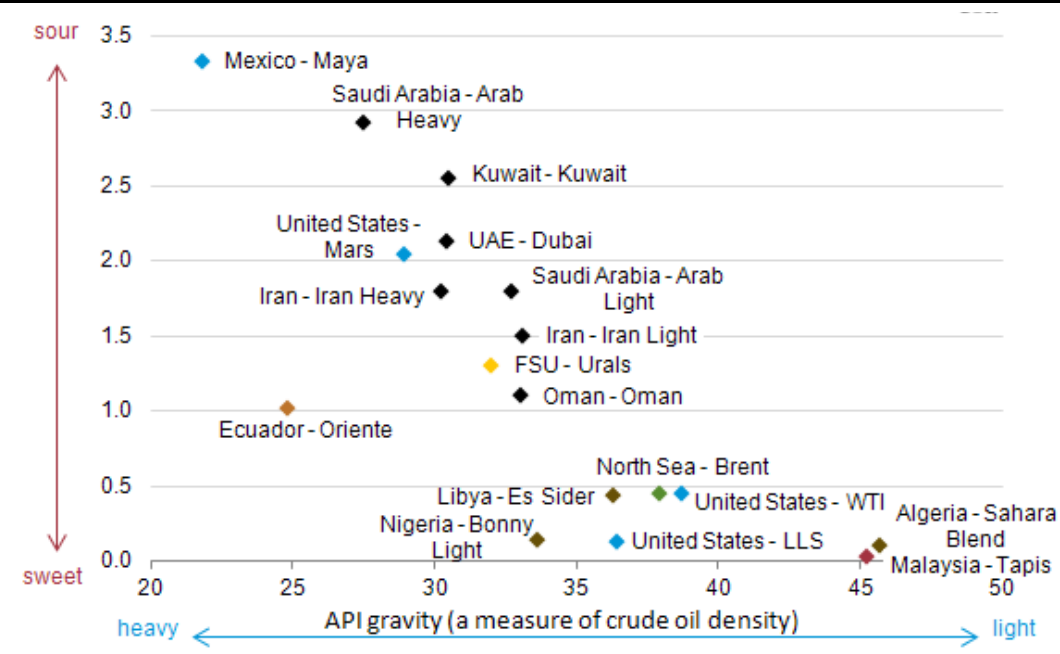

Figure2.1. Density and sulphur content of selected crude oils ${ }^{[5]}$

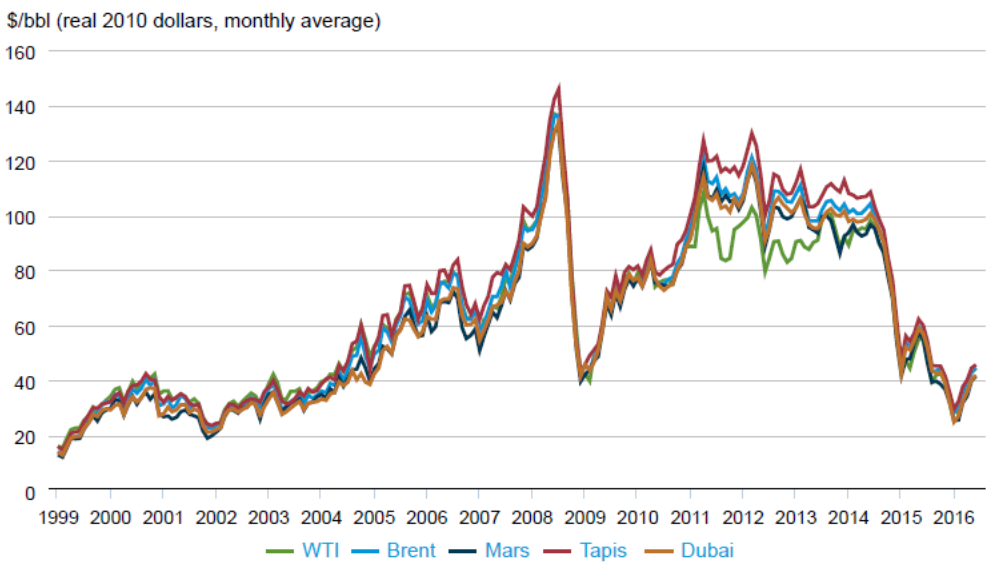

Figure2.2. Price movement of some crude oils ${ }^{[6]}$

\subsection{Factors that Account for Crude Oil Price}

\subsubsection{Supply and Demand}

The basic law of supply and demand affects oil prices. As demand increases (or supply decreases) prices should go up and as demand decreases (or supply increases), prices go down. The prices of gas and oil reserves are a reflection of the supply and demand pressures from a given time frame. When the demand of crude oil products is high, prices adjust to maintain supply levels for the future in consideration for current production levels. High prices on the other hand encourages production, supply levels increase and this results in the decrease in the price of oil and its products ${ }^{[7]}$.

\subsubsection{Production}

Before the 1970's the oil business was dominated by seven western companies, "Seven Sisters". These companies operated around the world and were responsible for significant oil field developments. The Seven Sisters comprised of the Anglo-Persian Oil Company, Gulf Oil, Standard Oil of California, Texaco, Royal Dutch Shell, Standard Oil of New Jersey and Standard Oil Company of New York ${ }^{[8]}$. After the oil crisis in the 1970's and following political developments, oil production around the world became nationalized to a large extent. Today multinational companies control only about $5 \%$ of global oil reserves, but have remained as important partners in the oil market and development of the petroleum industry.

The largest oil producers are roughly the countries with the largest reserves as in the case of the Middle Eastern producing countries. Some developed economies have however, managed to utilize their reserves more effectively and have a lower reserve-to-production ratio whilst others that produced at higher rates are experiencing production decline due to depleting reserves. It is notable that especially Russia and the United States produce at a very high rate despite their relatively lower reserves. 
Since the 1970's some of the most notable oil producers have channeled their interests through the Organization of Petroleum Exporting Countries (OPEC). Other oil producers are very loosely represented through the International Energy Agency (IEA), which is a sister organization of and sharing the same developed member countries with OECD (Organisation for Economic Co-operation and Development). Significant producers and/or consumers such as Russia, China and India are however not members of either of these organisations ${ }^{[3]}$.

Global supply of oil is also affected by the fact that oil is a nonrenewable natural resource which is subject to conditions such as the location of reserves, the amount and physical properties of oil found in different reservoirs and the geological formation in which the oil is found. Some of these physical factors determine the costs of extraction from a particular reserve. In addition, it takes time and substantial investment to discover new reservoirs and to develop them. Thus, the factors that affect the global production of oil from existing fields in oil-exporting countries drive near-term oil prices ${ }^{[9]}$.

Technological progress on the other hand has increased the supply of crude oil and reduced the cost of marginal oil production. New technology, such as horizontal drilling, enhanced oil recovery has increased the ultimate recovery of reservoirs and the quantities of oil that can be produced. Oil deposits in deep offshore which were previously inaccessible can now be harnessed, and the cost of extracting and processing unconventional oil reserves has also been reduced through technological advancements in the industry ${ }^{[10]}$.

\subsubsection{Consumption}

Crude oil consumption is driven by the demand for refined oil products. There are large regional differences in consumption rates, with the developed OECD countries such as (Denmark, Germany, Luxembourg and the United Kingdom) representing about $50 \%$ of world demand. Demand for crude comes also from many sources, but two main sectors: transportation and industry cover about $85 \%$ of the total globally with residential, commercial, electric power generation and heating representing the remaining. It is notable that industries use may be substituted by other sources of energy such as coal and hydroelectricity, transportation however is almost solely dependent on crude oil products for its energy needs. Long periods of low fuel prices have led the transportation infrastructure and industry to be built around oil products and even with higher oil prices substituting technologies have had hard times gaining foothold. In the industrial sector, oil is mainly used for power generation or heat for industrial purposes. They are also used as raw materials for manufacturing products such as plastics, industrial chemicals and asphalt ${ }^{[3]}$.

In recent times, China's economy has contributed significantly to oil consumption with consumption rates surpassing the second largest importer of liquid fuels, the United States in the late 2013. According to the EIA, China is expected to burn through 3 million more barrels per day in 2020 compared to 2012, accounting for about one-quarter of global demand growth over that time frame ${ }^{[11]}$.Figure 2.3 shows the consumption and production of oil by region revieved in the year 2015 .

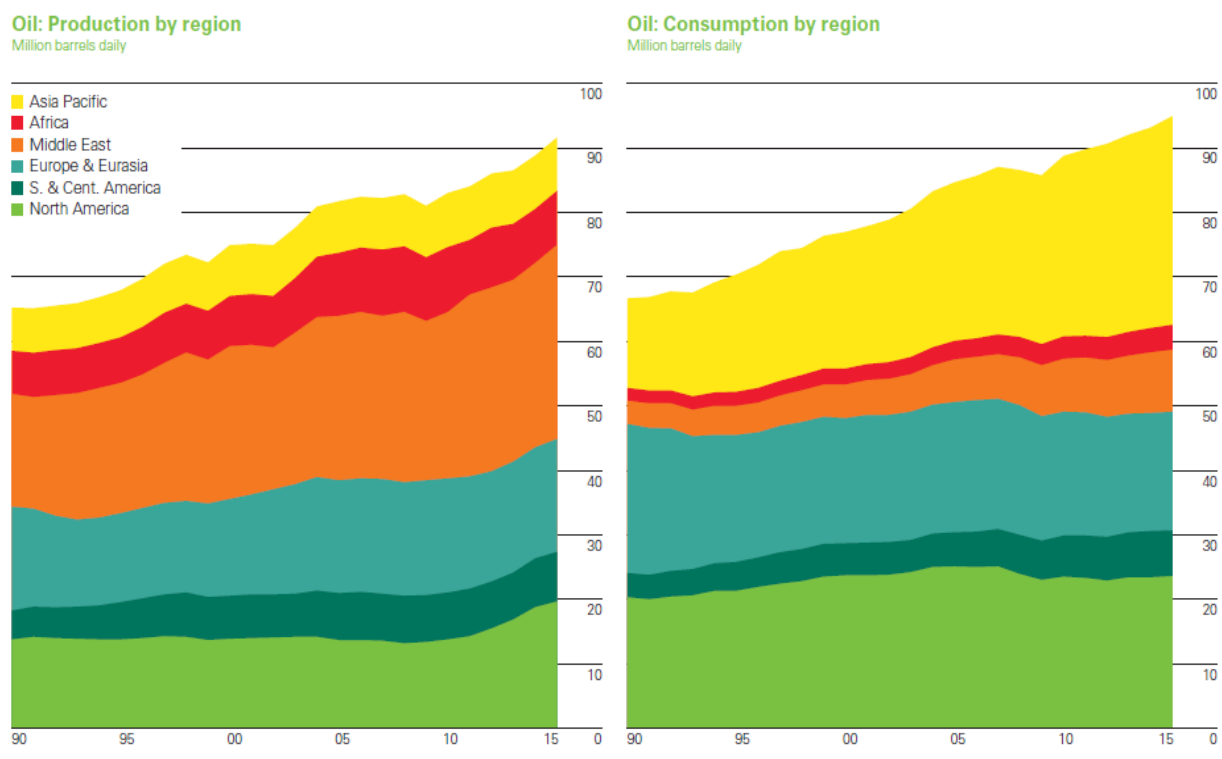

Figure2.3. Oil production and consumption by region ${ }^{[1]}$ 


\subsubsection{Organisation of Petroleum Exporting Countries (OPEC)}

The Organisation of the Petroleum Exporting Countries (OPEC) is a permanent, intergovernmental organisation, created at the Baghdad Conference on September 10 - 14, 1960, by Iran, Iraq, Kuwait, Saudi Arabia and Venezuela. The five Founding Members were later joined by other member countries such as Nigeria 1971 and Libya in 1962 and as of 2015 has 13 member countries. OPEC's objective is to coordinate and unify petroleum policies among member countries, in order to secure fair and stable prices for petroleum producers; an efficient, economic and regular supply of petroleum to consuming nations; and a fair return on capital to those investing in the industry ${ }^{[12]}$.

OPEC accounts for an estimated $42 \%$ of global oil production and $73 \%$ of the world's "proven" oil reserves, giving OPEC a major influence on global oil prices. OPEC decisions have come to play a prominent role in the oil market and international regulations. The effect can be particularly strong when conflicts or civic disorders lead to unreliable and extended interruptions in supply. In the 1970s, OPEC's restrictions in oil production led to significant price spikes along with OPEC's revenue and wealth, with long-lasting and far-reaching consequences on the global economy. OPEC started setting production targets for its member nations in 1980, and generally a reduction of these production targets lead to an increase in oil prices ${ }^{[12]}$.

\subsubsection{Futures Market}

The price of oil as we know it is actually set in the oil futures market. An oil futures contract is a binding agreement that gives one the right to purchase oil by the barrel at a predefined price and date in the future and clients purchase futures to hedge against crude price fluctuations that adversely affects profitability ${ }^{[13]}$. Futures prices above spot prices that lead to expectations of higher prices in the future can influence oil producers withhold their oil in order to sell it at latter date for higher profits. This can reduce current supply of oil and substantially affect prices ${ }^{[14]}$.

\subsubsection{Speculators and Brokers}

Brokers and market speculators have an influence on oil prices. An example of a speculator would be someone who is just guessing the price direction and has no intention of actually buying the product. According to the Chicago Mercantile Exchange (CME), the majority of futures trading is done by speculators as less than $3 \%$ of transactions actually result in the purchaser of the futures contract taking possessing of the commodity being traded ${ }^{[15]}$. In 2008, it was thought that speculators were bidding up oil prices and creating an unsustainable price level (up to $\$ 140$ per barrel). By late 2009, prices fell to $\$ 30$ per barrel because the demand was not present to support the inflated price level ${ }^{[16]}$.

Also market sentiment is a key factor in determining oil prices. For example, the mere belief that oil demand will increase dramatically at some point in the future can result in a dramatic increase in oil prices in the present as speculators and hedges also snap up oil futures contracts ${ }^{[15]}$.

\subsubsection{Exchange Value of the Dollar}

Crude oil is traded globally in, US Dollars while consumers use local currencies to buy petroleum products. When the US dollar depreciates against other currencies, countries with non-dollar appreciating currencies enjoy cheap oil, while consumers in US Dollar-pegged countries pay a higher price for the same barrel of oil. Changes in the US Dollar will therefore affect world oil demand. Depreciation of the US Dollar versus the appreciation of other currencies will decrease the cost of buying a dollar. This will increase the demand for crude oil, in other currencies than the US Dollar which consequently leads to increases in prices. A negative relationship between the US Dollar exchange rate and the crude oil price changes is thus expected ${ }^{[14]}$.

\subsubsection{Government in Consumer and Producer Countries}

About $94 \%$ of the world's proved reserves are controlled by governments, thus political decisions to a large extent control the availability, supply and consumption of oil.

Firstly, political imperatives have a major influence on the investments in exploration and production that will consequently affect future prices. Oil investments in producing countries must compete with a number of other priorities, including social and health programmes and other investments to diversify the economy away from dependence on oil production. These other priorities reduce revenue 
available for investment in oil production capacity subsequently affecting prices. For example, as oil prices rose in 2007, ExxonMobil, one of the largest oil companies, was investing \$20 billion annually in capital and exploration projects, while according to OPEC statistics, only three member nations were investing more than $\$ 20$ billion in cumulative capital expenditures on upstream projects to come on-line in 2004 through 2012.

Governments also provide subsidies on petroleum products for transport, agriculture, industrial and other economic activities to control inflation. These subsidies shield certain sectors from oil price increases. Thus, in countries with subsidies, crude oil demand is largely unresponsive to price changes. BP estimates that these countries that currently or recently subsidized gasoline and other oil products such as China, India, Ghana and Bahrain accounted for $96 \%$ of the world's increase in oil consumption in 2007.

On the other hand, in countries without subsidies, demand for oil generally becomes stagnant or falls as global crude oil prices ${ }^{[9]}$.Energy policy and taxes in oil-rich countries also affect the price of oil. If a government bans oil exploration in a place with proven reserves, such as the Gulf of Mexico, it could lead to a reduction in oil supply. Petroleum agreement regulations and requirements imposed by countries on multi-national oil companies can increase the cost of production and eventually oil prices [16].

\subsubsection{Political Tensions}

The world supply of oil is reduced by war, terrorism, and guerrilla activities that are as a result of political instability or conflict. Political instability in countries especially oil producing zones such as the Middle East, has had a significant impact on oil production and price. These tensions may arise due to the eruption of long-standing historic rivalry among countries and tribes, religious differences and the control of power and valuable resources like petroleum. Tensions involving Iran have been associated with some of the highest oil prices in history, and the easing of these tensions have led to price reductions from their record high levels. The largest nominal increase in oil prices prior to the peak in 2008, (\$ 10.75 per barrel), occurred on June 6, 2008 following the remark by an Israeli cabinet minister that Israel might attack Iran. Other events involving Iran, ranging from a missile test to the easing of political tensions, were associated with both increases and decreases in oil prices in July 2008.

Iraq's production has been reduced over the past several decades as a result of extended war periods. The intervening years of relative peace were associated with recovery in the levels of production. Iraq's 2008 production of 2423 thousand barrels per day, following years of recovery from its low production levels in 2003, is still only approximately $69 \%$ of Iraq's peak production of 3489 thousand barrels per day in 1979 prior to the Iran-Iraq war.

Violence and insurgent activities in the Niger Delta negatively affects Nigerian oil production. The recurring abduction of foreign workers, attacks on pipelines and sabotage of oil infrastructure have reduced Nigeria's production output.

News of unrest in oil producing zones and those associated with oil activities all over the world results in high oil prices ${ }^{[9]}$.

\subsubsection{Economic Factors}

Like many other commodities, oil prices are linked to the economic activities of most countries. Demand and consumption of oil by all sectors increases with economic, industrial and population growth and decreases when there is economic recession.

Oil importing countries, such as the US and China, will increase their oil demand as a result of economic growth eventually leading to higher oil prices. Oil exporting countries, gain maximum oil profit and economic wealth as a result of higher prices from these increasing demands. If oil prices remain at high levels, economic growth in importing nations might decline, causing a decline in oil demand and prices. High prices will also lead to increases in petroleum investments, exploration and development budgets leading to new oil discoveries and increased supply which over time will cause prices to decline ${ }^{[14]}$. 


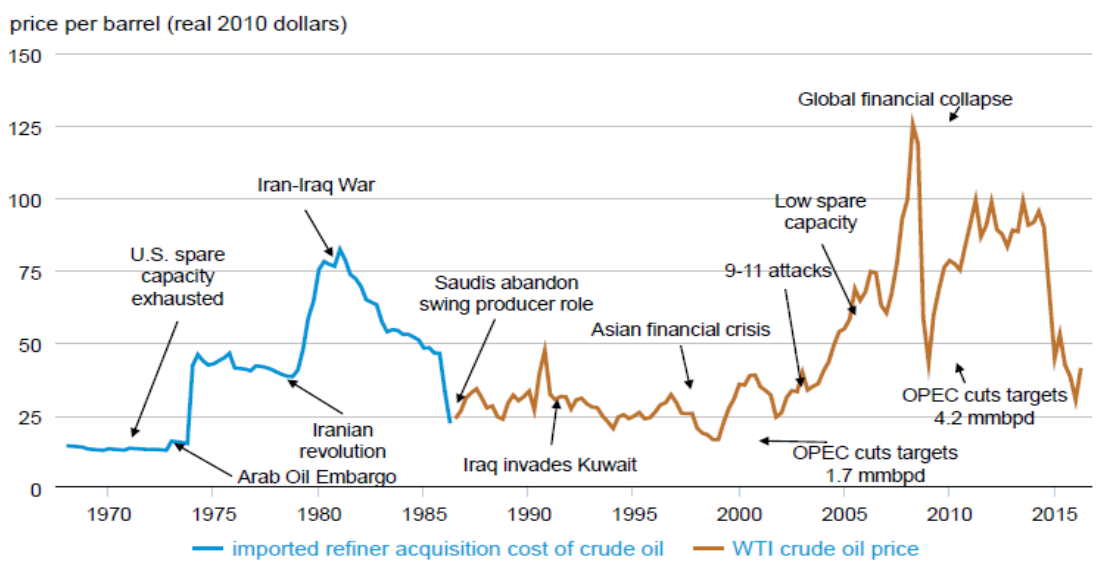

Figure2.4. Geopolitical and economic effects on crude price ${ }^{[6]}$

\subsubsection{Natural Factors}

Like most commodities, seasonal changes in weather affects the demand for oil. In winter, more heating oil is consumed, and in summer, more gasoline is used as people drive more. Even though markets know when to expect these increased demand periods, the price of oil rises and levels out seasonally every year. Extreme weather conditions such as hurricanes, tsunamis and thunderstorms especially in major oil producing regions can physically affect production facilities and infrastructure, disrupting the supply of oil and inducing price hikes ${ }^{[16]}$.

When Hurricane Katrina struck the southern United States in 2005, affecting $19 \%$ of the US oil supply, the price of a barrel of oil to rose by \$3. In May 2011, the flooding of the Mississippi River also led to oil price fluctuation ${ }^{[15]}$.

\subsubsection{Other Energy Sources}

The impact of crude oil price on other energy sectors like renewable energy and vice versa is not definitive. Factors such as legislative mandates, competitive substitutes and varying regional impact must be considered. The dependency on crude oil has been diminishing in the face of increasing development and continual drop in the capital costs of other energy technologies.

Due to recent oil price increases and volatility, countries have placed concerted efforts on reducing dependence on crude oil. Energy efficient and electric/hybrid vehicles as well as residential solar installations are gaining market share and popularity.

Broadly speaking, crude oil and other energy sources such as renewables, natural gas and hydroelectric are used to satisfy different parts of global energy requirements. While crude remains the largest primary source of energy, it is generally used in the production of transportation fuels whilst renewable energy is primarily used to generate power (electricity).

Thus crude oil does not have direct substitutes, and therefore when the prices of one energy supply increases, the demand for the other does not always increase. The exception to this comparison is liquid transport bio-fuels e.g. bio-diesel, bio-jet fuel and bio-ethanol which directly compete with crude oil products. The price of crude can thus be influenced by increasing popularity of bio-fuels ${ }^{[17]}$.

Natural gas and crude oil are also close substitutes for each other in regions where both are supported by technology, infrastructure and markets. Advances in technology now allow end consumers to switch between fuels. If the price of one energy source rises significantly, consumers move to other energy source. This increases demand for the second energy source and its price then also increases ${ }^{[7]}$.

\subsubsection{Refinery Capacity}

The global refinery capacity or utilization is defined as the maximum amount of crude oil that can be processed in a calendar year divided by the number of days in the corresponding year ${ }^{[18]}$.The efficiency and productivity of refineries predict the amount of crude oil products available for consumption. Disruptions and breakdown at refineries can cause a temporary loss of petroleum products available for supply. Changes in refinery output and ability to process crude thus influences crude oil prices. 
Olimb and Ødegård in 2010 stated that, refinery utilization rates affect crude oil prices based on the ability of refineries to convert crude oil to final products. High refinery utilization rates may signify shortages in the supply of petroleum products causing an increase in petroleum products and crude oil. On the other hand, high refinery capacities might indicate flooding of petroleum products into the market causing a decrease in prices ${ }^{[14]}$.

\section{CONClusion}

This paper considered the oil industry and the extraction process of crude oil. It further highlighted on crude oil properties and characteristics and how they affect the quality and consequently the pricing of the various crude oil benchmarks.

From the review, it can be established that these individual factors or a combination of some of these factors can cause oil price volatility. Excess production of crude oil can lead to surplus and price reduction whilst excess consumption can also drive prices up. Increasing popularity of other energy sources can also lead to a reduction in oil as well as its price. The atmosphere of geopolitical tensions and instability is mostly associated with higher oil prices. Other factors such as the value of the dollar, government decisions in producing and consuming nations and futures market are also contributory factors in oil price determination.

Global crude oil prices thus change overtime and cannot be attributed to one single market. It is a highly complicated market system dependent on several variables.

\section{ACKNOWLEDGEMENTS}

The authors would like to extend their warmest appreciation first to the Almighty God for wisdom and understanding, and also to the following individuals for their technical advice and support in bringing this paper to print:Mr Kofi Kamasa, Prof Sunday Sunday Ikiensikimama

\section{REFERENCES}

[1] British Petroleum (2016), "2015 in Review”, BP Statistical Review of World Energy Journal 2016, $65^{\text {th }}$ ed., pp. $1-43$.

[2] McCain Jr, W. D. (1990), The Properties of Petroleum Fluids, PennWell Books, Tulsa, Oklahoma, $2^{\text {nd }}$ ed., pp. 1-10.

[3] Happonen, J. (2009), “A Review of Factors Determining Crude Oil Prices”, Unpublished MSc Thesis Report, Helsinki School of Economics, Finland, pp. 1 - 24.

[4] Mian, M. A. (2011), Project Economics and Decision Analysis: Deterministic Models, PennWell Books, Tulsa Oklahoma, Vol. 1, pp. $1-160$.

[5] Energy Information Administration (2012), "Crude oils have different quality characteristics", U.S. Energy Information Administration webpage, https://www.eia.gov/todayinenergy/ detail.php?id=7110. Accessed: February 2, 2017.

[6] Energy Information Administration (2016), "What drives crude oil prices?", U.S. Energy Information Administration webpage, https://www.eia.gov/finance/Markets/reports_ presentations/eia_what_drives_crude_oil_prices.pdf. Accessed: January 25, 2017.

[7] Seth, S. (2015), "Do Oil and Natural Gas Prices Rise and Fall Together", Investopedia webpage, http://www.investopedia.com/articles/active-trading/032515/do-oil-and-natural-gas-prices-riseand-fall-together.asp. Accessed: February 2, 2017.

[8] Yergin, D. (1991), The Prize: The Epic Quest for Oil, Money \& Power, Simon \& Schuster, New York, pp. $1-78$.

[9] King, K., Deng, A., Metz, D. (2011), “An Economic Analysis of Oil Price Movements: The Role of Political Events and Economic News, Financial Trading, and Market Fundamentals", Bates White Economic Consulting, Washington DC, pp. $1-52$.

[10] Mostert, W. (2004), "Factors influencing the International Price of Oil in the Medium to LongTerm", www.mostert.dk/pdf/Factorsinfluencingpriceofoil.pdf. Accessed: February 3, 2017, pp. 1 -10 .

[11] Cunningham, N. (2015), “Top Five Factors Affecting Oil Prices in 2015”, Oil Price.com webpage, http://oilprice.com/Energy/Energy-General/Top-Five-Factors-Affecting-Oil-Prices-In2015.html. Accessed: January 25, 2017. 
[12] OPEC (2017), "Organisation of Petroleum Exporting Countries", OPEC webpage, http://www. opec.org/opec_web/en/. Accessed: February 8, 2017.

[13] Kosakowski, P. (2016), "What Determines Oil Prices?", Investopedia webpage, http://www. investopedia.com/articles/economics/08/determining-oil-prices.asp. Accessed: February 2, 2017.

[14] Olimb, M., Ødegård, T. M. (2010), "Understanding the Factors Behind Crude Oil Price Changes A Time-varying Model Approach",Unpublished MSc Thesis Report, Norwegian University of Science and Technology, pp. $1-45$.

[15] Anon (2015), “The Determinants of Oil Prices", Investopedia webpage, http://www. investopedia.com/ask/answers/012715/what-causes-oil-prices-fluctuate.asp. Accessed: January 25, 2017.

[16] Anon (2012), "Ten Factors that Affect the Price of Oil", Clover Global Solutions webpage, https://clwsolutions.wordpress.com/2012/04/30/factors-affect-price-of-oil/. Accessed: January 25, 2017.

[17] Le, B. (2015), "Crude Oil's Impact on Renewable Energy: Energy Alternative or Energy Staple?",http://www.altenergymag.com/article/2015/06/crude-oil\%E2\%80\%99s-impact-onrenewable-energy-energy-alternative-or-energy-staple/20384. Accessed: February 9, 2017.

[18] Möbert, J. (2007), "Crude oil price determinants", Published MSc Thesis Report, Germany, Darmstadt Discussion Papers in Economics, No. 186, 32 pp. 